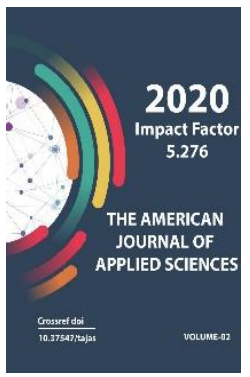

\title{
Methods Of Teaching And Analysis Of Sewing Methods In Applied Art
}

\author{
Gulnora Abdumalikovna Khakimova \\ Senior Lecturer Of The Department Of Fine Arts And Engineering Graphics, Uzbekistan.
}

Journal Website:

http://usajournalshub.c

om/index,php/tajas

Copyright: Original content from this work may be used under the terms of the creative commons attributes 4.0 licence.

\section{ABSTRACT}

The article deals with general issues on the methodology of teaching sewing, including the goals and objectives of sewing, education in the process of sewing circles, types of circle plans, their creation, types of circle activities, forms of labor organization, sewing description of specialty, circle leaders topics such as preparation for the school year and classes, analysis of its observation, learning to organize an exhibition of creative work.

\section{KEYWORDS}

Methodology of teaching sewing, goals and objectives of sewing, types of circle plans, labor organization, sewing description of specialty.

\section{INTRODUCTION}

Training in the organization of classes in the sewing circle, the material base of the room for the circle, manual, machine, ironing, the use of fabrics for women's and children's clothing, their design, artistic decoration The training involves the formation of theoretical knowledge, skills and abilities to teach the preparation of small details, sewing and repair of women's, baby and girls' clothes, national costumes. Methods of teaching sewing are taught in connection with special disciplines such as pedagogy, psychology, painting, 
design and artistic decoration of garments, sewing fabrics, sewing technology and equipment, artistic processing of ironing, embroidery, educational practice "Sewing Technology". On the basis of the knowledge, skills and abilities acquired in these disciplines, students are taught to prepare for lessons, write developments, prepare exhibitions.

\section{MATERIALS AND METHODS}

The Industrial Revolution shifted the production of textiles from the household to the mills. In the early decades of the Industrial Revolution, the machinery produced whole cloth. The world's first sewing machine was patented in 1790 by Thomas Saint. By the early 1840 s, other early sewing machines began to appear. Barthélemy Thimonnier introduced a simple sewing machine in 1841 to produce military uniforms for France's army; shortly afterward, a mob of tailors broke into Thimonnier's shop and threw the machines out of the windows, believing the machines would put them out of work. By the 1850s, Isaac Singer developed the first sewing machines that could operate quickly and accurately and surpass the productivity of a seamstress or tailor sewing by hand.

While much clothing was still produced at home by female members of the family, more and more ready-made clothes for the middle classes were being produced with sewing machines. Textile sweatshops full of poorly paid sewing machine operators grew into entire business districts in large cities like London and New York City. To further support the industry, piece work was done for little money by women living in slums. Needlework was one of the few occupations considered acceptable for women, but it did not pay a living wage. Women doing piece work from home often worked 14-hour days to earn enough to support themselves, sometimes by renting sewing machines that they could not afford to buy.

\section{RESULT AND DISCUSSION}

As a result of studying the subject, students should have the following skills:

- be able to make a plan of a sewing training circle;

- be able to organize a sewing circle;

- be able to work with sewing materials and prepare an exhibition for training;

- be able to operate and overhaul machines;

- be able to perform the types of work used in women's and children's clothing, with the help of which they can process small details and teach the members of the circle;

- be able to sew a set of baby clothes, women's and children's nightgowns, gowns, dresses, national costumes and teach them to the members of the circle;

- be able to repair clothes and find ways to convey this topic to students.

- As a result of studying the subject, students gain the following knowledge should have.

- good knowledge of each item of the Regulations on children's centers "Barkamol Avlod";

- know information about sewing products, types and requirements to them;

- to know the methods and ways of teaching to take into account the fiber content and properties of fabrics in sewing technology, to determine the direction of the right, vice versa, height, rope;

- to know the methods of creating jobs for handicrafts and teaching them to perform them; 
- rules for creating a workplace for machine work and training in machine sewing;

- methods of teaching design, art decoration in women's and children's clothing;

- methods of teaching step-by-step sewing of women's and children's clothes;

- methods of teaching the production of blouses, European shirts, gowns, raglans, single-breasted shirts, national shirts, women's and children's shirts with the necessary, intricate shapes;

- know the methods of teaching sewing repair;

- Recommendations on modern information and pedagogical technologies in teaching science. Today, special attention is paid to the proper organization of children's leisure time, ie out-of-school and out-of-class education. The Regulation of the Cabinet of Ministers on Barkamol Avlod Children's Centers is the main document in the proper organization of children's leisure time. The use of modern information and pedagogical technologies in the training of future leaders of the circle remains a requirement of the times. In this regard, the following should be taken into account in the training of qualified junior specialists in professional colleges.

- The knowledge and skills acquired in the teaching of specialty subjects should be based on the requirements of state educational standards.

- The content of vocational education must meet the requirements of the level of scientific, technical and technological development.

- Use modern teaching aids - slides, multimedia, and other computer programs.
- In the organization of practical work, seminars on science, the teacher should teach students the use of information and pedagogical technologies, and in such classes the student should become a key figure.

- The room should have a computer, overhead projector, a set of resources from the Internet for use by students and pupils. They should be used by the teacher in each lesson.

- The room should have samples of educational works, exhibitions on modern information and pedagogical technologies. Tailoring - practical training on the subject of teaching methods of sewing and instructions for the organization of independent work practical work on the subject of teaching methods of sewing is organized in order to strengthen in practice the theoretical knowledge acquired on the topics specified in the program. The teacher organizes practical work based on the level of knowledge of the student and the conditions of teaching. In the organization of practical work, it is advisable to recommend topics in advance and give students a plan. Practical work is aimed at independent performance of students, taking into account the knowledge acquired in all special subjects. Of course, the teacher will give a referral for practical work. Every practical work must be checked and evaluated. Special attention should be paid to the independent work of students in the organization of practical work. Particular attention should be paid to the use of non-traditional methods in the organization of practical work. In order to further strengthen the knowledge acquired in the process of 
practical work, to increase their creative activity, assignments from independent work are taken into account. Deadlines for submission of independent work are set. Assessment of independent work is recorded in a separate journal or in the teacher's notebook, and the average grade is transferred to the main journal at the end of the semester.

You've sewn for years and you know what you're doing, but teaching someone else everything you know can be daunting. Where do you begin when you're teaching sewing lessons?

First, come up with a supply list with the materials you expect your students to have with them. Most classes require students to bring their own sewing machine, bobbins, and thread are the bare minimum. Inexpensive fabric, like fat quarters, is good for those first few lessons too. Try not to overwhelm the students by asking them to have sewing tools they will not need immediately, but ask them to have enough tools that they will be able to practice and sew on their own when they are not with you.

While it's cumbersome for students to carry their sewing machines to their lessons, it's best for them to learn on their own machines, as each model has its own quirks to get used to. It's common for new sewers to come to their lessons with cheap or old sewing machines because they're hesitant to invest money in a newer model before they've perfected their craft. If you're not familiar with their machine, take a few minutes to test it out before you start your lessons to make sure it's working correctly--if it's not, a novice sewer may not even realize it.

Sewing Lesson Plans. Your lesson plan does not have to be elaborate or detailed. It's good to be prepared for your teaching schedule to change with your students' pace of learning. Remember that not everyone is going to take to sewing immediately, and no one starts off at the same pace as someone who has been sewing for years.

The first time someone sits down at the sewing machine, they must master controlling the machine. Because you have been sewing for years, you tend to forget just how much skill is involved in getting started.

Always begin with the machine unthreaded and sewing on paper. Mastering operating the machine without the frustration of thread tangling and knotting is much easier.

Speed Control. Mastering speed is one step in getting full control of the sewing machine. Many machines have a turtle and hare setting to control speed, but some do not. Without even sewing paper, allow the student to experiment with how fast or slow they can make the machine go. Let them practice until they can maintain an even speed on the sewing machine.

When someone is unable to control the foot pedal, a small item, such as a thin bobbin or washers, can be placed under the edge of the foot pedal to prevent it from going at full speed. This is especially helpful for young people who want to sew. If the item under the foot pedal slips out of the way, place a piece of tape, sticky side up, under the foot pedal and under the item to stop the full depression of the foot pedal and hold the stopper in place.

If your student's legs are too short to reach the foot pedal, place the pedal on a thick book.

Sewing Paper. Print out practice sheets. Your goal will be to have the student sew an even 
distance from each line, not on the line. It is important that they learn to focus on watching a guide, not the sewing machine needle. Start with straight lines, including the edges of the paper, using the edge of the presser foot as a seam guide, then move on to the curved lines. Teach the students that the machine will feed the fabric and their job is to just guide the fabric (or paper, in this case) under the needle as it is sewn. Forcing the fabric under the needle can result in bent sewing machine needles and machine malfunctions.

Move on to sewing the paper with squares, teaching them to stop with the machine needle down so they can pivot at the corners.

As a last step in learning to control the sewing machine, teach the students how to thread their machine and explain about keeping the thread tails behind the needle. Using scraps of fabric, allow the students to experiment with sewing straight and curved seams, keeping an even seam allowance as they sew.

Sewing License. When you feel a student has mastered controlling the sewing machine, reward them with a sewing machine license.

The First Real Sewing Project. Once students master basic operating skills, it's time to start a real sewing project. The first project should be something that requires nothing more than straight lines and is simple enough to be finished in one lesson so that the student is able to have immediate gratification. Starting with an easy project so each student has a finished item is an important key to them learning before moving on to something more complicated that may take weeks to complete.

Choose a project and give the students a materials list so they are prepared for the next lesson. You can also prepare a kit so they are ready with the appropriate starting point and materials. If you do make a kit, be sure to talk about the details, such as preshrinking, fabric grain, fabric options, and pattern choice so that they know what they should look for when they go shopping on their own. If your kit contains the fabric cut for the project, demonstrate how you cut the fabric so they are capable of cutting their own fabric if they want to make the project on their own.

\section{CONCLUSION}

In conclusion, we can say, always have a printout of the directions for each student. This allows students to make the project again on their own.

Choose a simple sewing project. An envelopeback pillow can be used by any age group, and a potholder is always a useful item. A simple tote bag is handy to have on hand, and your students can take their work with them everywhere they go.

Allow the students to feel comfortable with finishing a simple project before moving on to a commercial pattern. Their first time sewing a commercial pattern should be a beginners' pattern, which helps students learn how to understand and read a pattern before trying to learn more detailed sewing techniques.

\section{REFERENCES}

1. Charter of the Barkamol Avlod ancestral center, state requirements. - T .: 2011

2. M.Abdullayeva, H.SH.Boboxonova. Methods of teaching sewing.-T.2010.

3. N.Gairova, H.Bobokhonova. Sewing technology and equipment - T .: 2007

4. Q.M.Abdullaueva.N.Gairova. Design, modeling and artistic decoration of garments.-T.:2010

5. R.I.Yegorova. Learn to sew. - T .: 1991. 
6. V.A.Ponkratova. Basics of sewing production training. - T .: 1993 .

7. Textbook for Vocational Colleges "Tailor". 2004

8. Magazines "Burda".

9. Holley, Linda A. (2007). Tipis, Tepees, Teepees: History and Design of the Cloth Tipi. Gibbs Smith. p. 87. ISBN 9781586855116.

10. W. D. Hammond-Tooke, ed. (1980). The Bantu-Speaking Peoples of Southern Africa. Taylor \& Francis. p. 119. ISBN 9780710007087.

11. Sekhri, Seema (2011). Textbook of Fabric Science Fundamentals to Finishing. PHI Learning Pvt. Ltd. ISBN 9788120341838.

12. Whiting, Gertrude (1971). Old-Time Tools \& Toys of Needlework. reprint; originally published 1928 by Columbia University Press. Courier Dover Publications. pp. 150-1. ISBN 9780486225173.

13. Webb, Mary (2006). Embroidery Stitches. Struik. pp. 155, 159, 170. ISBN 9781770074224.

14. Jump up to:a b Leslie, Catherine Amoroso (2007). Needlework Through History: An Encyclopedia. Greenwood Publishing Group. pp. xii. ISBN 9780313335488.

15. Carlson, Laurie M. (2003). Queen of Inventions: How the Sewing Machine Changed the World. Millbrook Press. p. 8. ISBN 9780761327066.

16. Perkin, Joan (1993). Victorian Women. London: John Murray (Publishers) Ltd. pp. 189-90. ISBN 0-7195-4955-8.

17. Valerie Steele, ed. (2010). The Berg Companion to Fashion. Berg. p. 618. ISBN 9781847885920.

18. http:// ziyonet.uz/ru Tikuv texnologiyasi

19. http:// www. tvorim.e-gloryon.com Rukodeliye

20. www.burda moden.com Burda jurnali2. 